\title{
Analisa Biogas Berbahan Baku Eceng Gondok dan Kotoran Sapi
}

\author{
Jatmiko Edi Siswanto*1, Adi Susanto² \\ 1,2Jurusan Teknik Mesin, Sekolah Tinggi Teknologi Nasional, Jambi \\ J1. Pattimura, Kenali Besar, Kota Baru, Kota Jambi, Jambi 36361 \\ e-mail: *jatmikoedis@gmail.com
}

\begin{abstract}
Diterima: 29 April 2018 / Disetujui: 31 Mei 2018 / Dipublikasi online: 30 Juni 2018
\end{abstract} https://doi.org/10.22437/chp.v3i1.4806

\begin{abstract}
ABSTRAK
Teknologi biogas merupakan teknologi yang memanfaatkan kandungan bahan organik dari pertumbuhan mikroorganisme yang berpotensi untuk menghasilkan biogas. Permasalahan teknologi biogas saat ini berkaitan dengan sistem peralatan, bahan baku dan besarnya tekanan biogas yang masih belum diketahui. Bahan utama pembuatan biogas dalam penelitian ini menggunakan eceng gondok, kotoran sapi dan penambahan air dengan perbandingan 25\%: $75 \%$ : 5 liter, 75\%: 25\%: 5 liter, dan 50\%: 50\%: 5 liter. Metode pengujian awal mengunakan digister galon 20 liter dan pada pengujian akhir menggunakan digester drum 200, yang dilengkapi termometer, manometer dan ban untuk penampung gas. Berdasarkan hasil dari pengujian awal dalam penelitian ini diketahui bahwa selama 15 hari fermentasi perbandingan 25\%: 75\%: 5 liter merupakan komposisi dengan proses fermentasi tercepat dan tekanan gas tertinggi terjadi pada hari ke-6 yaitu sebesar 900 Pa. Berdasarkan hasil pengujian akhir diketahui bahwa pembentukan biogas dengan menggunakan digister drum 200 liter dengan perbandingan 25\%: 75\%: 5 liter, terjadi pada hari ke-1 sampai hari ke-21 dan pencapaian tekanan gas optimal terjadi pada hari ke-7 dengan tekanan sebesar 10.000 Pa.
\end{abstract}

Kata kunci: Analisa Biogas; Enceng Gondok; Kotoran Sapi

\begin{abstract}
Biogas technology is a technology that utilizes organic matter from the growth of microorganisms that have the potential to produce biogas. Currently, biogas technology problems are related to equipment systems, raw materials and the amount of biogas pressure that are still unknown. The main ingredients of biogas production in this research were Eceng Gondok, cow dung and water addition with ratio 25\%: 75\%: 5 liter, 75\%: 25\%: 5 liter and 50\%: 50\%: 5 liter. The initial test method used 20 liters of gallon digester and the final test using 200 liters drum equipped with thermometer, manometer and tire for gas container. Based on the results of the initial test from this research, it was known that for 15 days, comparison fermentation of 25\%: 75\%: 5 liter was the composition with the fastest fermentation process and the highest gas pressure occurred on the 6th day with a pressure of $900 \mathrm{~Pa}$. Based on the final test results, it was known that the formation of biogas by using 200 liters drum digiter with a ratio of 25\%: 75\%: 5 liters, occurred on the 1st day until the 21st day and the optimal gas pressure occurred on the 7th day with a pressure of $10.000 \mathrm{~Pa}$.
\end{abstract}

Keywords: Biogas analysis; Eceng Gondok; Cow Dung 


\section{PENDAHULUAN}

Kebutuhan akan penggunaan energi semakin meningkat seiring dengan pertambahan jumlah penduduk dan peningkatan konsumsi oleh masyarakat akibat penggunaan berbagai macam peralatan untuk menunjang kenyamanan dalam kehidupan. Suber energi yang selama ini digunakan sebagaian besar berasal dari bahan bakar fosil, seperti batubara, minyak bumi, gas alam dan lain-lain. Bahan bakar fosil merupakan sumber energi yang tidak terbarukan, yang semakin hari semakin menipis ketersediaannya oleh karena itu, untuk mengganti penggunaan energi tidak terbarukan diperlukan sumber energi alternatif yang mampu mengurangi laju pemakaian energi fosil.

Indonesia sebagai negara tropis memiliki sumber energi baru terbarukan yang melimpah sebagai energi alternatif pengganti energi fosil. Salah satu energi alternatif tersebut adalah pemanfaatan energi biogas. Biogas adalah gas produk akhir dari pencernaan degradasi anaerobik .dalam lingkungan tanpa oksigen atau tanpa udara oleh bakteri-bakteri menthanogen. Biogas merupakan salah satu sumber energi alternatif terbarukan yang paling efisien dan efektif. Teknologi biogas dilakukan dengan memanfaatkan kandungan bahan organik untuk pertumbuhan mikroorganisme yang potensial menghasilkan biogas (Nadiriah dan Triwikantoro, 2014).

Karakteristik bahan baku biogas harus memiliki karakteristik yang khas agar keberhasilan proses fermentasi substrat berjalan dengan lancar. Idealnya, bahan baku biogas di pilih dan di campur dalam proporsi tepat untuk menghasilkan biogas yang berkualitas. Kandungan air, derajat keasaman $\mathrm{pH}$ dan kualitas bahan baku biogas merupakan hal yang sangat penting perlu diperhatikan. Karakteristik bahan baku yang harus diperhatikan $\mathrm{C} / \mathrm{N}$ adalah perbandingan jumlah karbon $(\mathrm{C})$ dengan nitrogen $(\mathrm{N})$ dalam suatu bahan. Bahan baku yang biasa di jadikan biogas adalah kotoran ternak gulma air dan limbahlimbah yang dihasilkan dari produk samping pertanian dan .pemanfaatan limbah eceng gondok dapat dijadikan bahan sebagai sumber Carbon(C) dan Nitrogen(N) dalam pembentukan gas metana. 

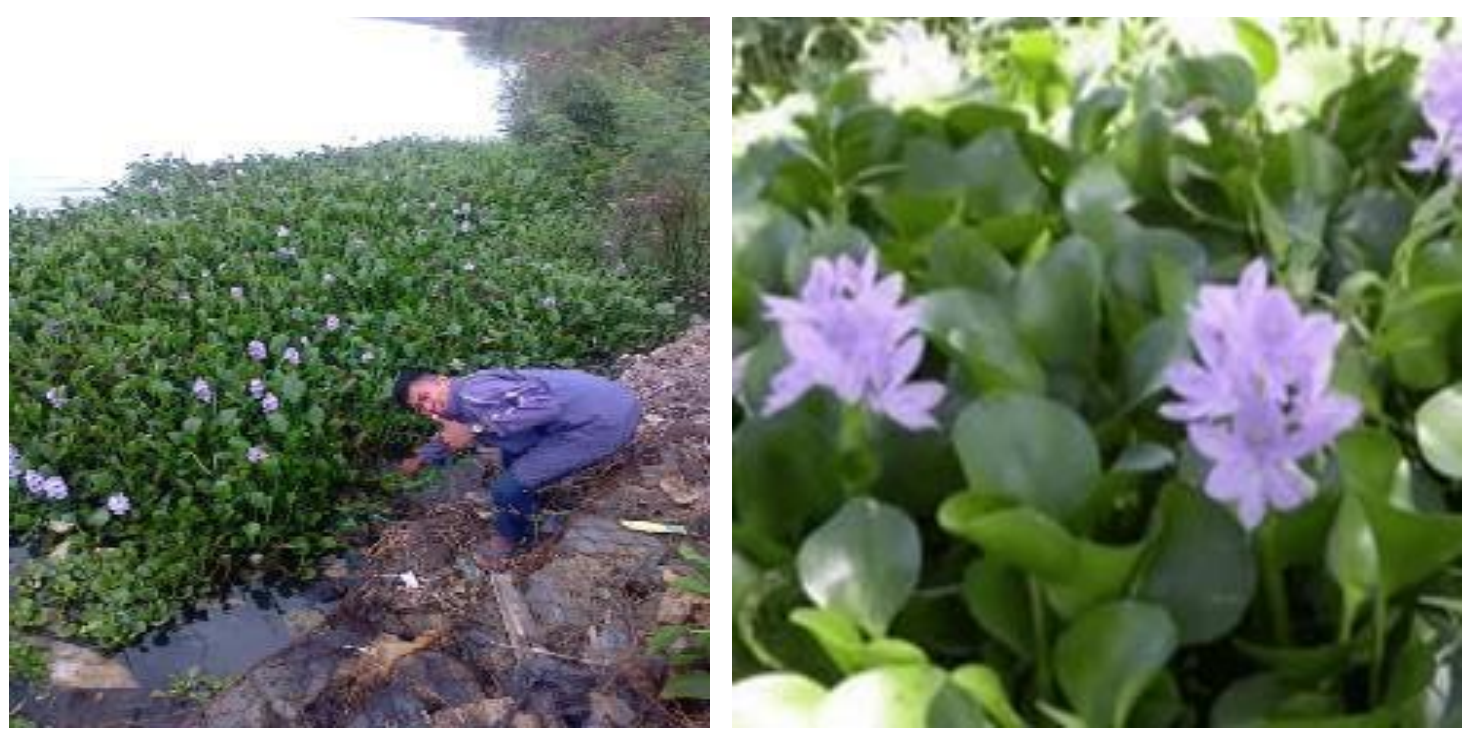

Gambar 1. Gulma enceng gondok

Eceng gondok merupakan tanaman gulma (Gambar 1) di wilayah perairan yang hidupnya terapung pada air dan dengan mudah menyebar melalui saluran air ke badan air lainnya. Perkembang biakannya yang demikian cepat menyebabkan tanaman eceng gondok telah berubah menjadi tanaman gulma perairan. Kotoran sapi sebagai limbah peternakan juga berpotensi dapat dijadikan bahan sebagai sumber $\mathrm{C}$ dan $\mathrm{N}$ dalam pembentukan gas metan. Feses sapi mengandung hemisellulosa sebesar 18,6\%, selulosa 25,2\%, lignin 20,2\%, nitrogen $1,67 \%$, fosfat $1,11 \%$ dan kalium sebesar $0,56 \%$. Di lain pihak, pemanfaatan limbah peternakan (kotoran ternak) merupakan salah satu alternatif yang sangat tepat untuk mengatasi naiknya harga pupuk organik dan ketersediaan bahan bakar minyak yang semakin menipis (Darnegsih, 2016).

Manfaat dan keuntungan dari biogass atau methan dapat digunakan untuk berbagai keperluan seperti halnya gas alam. Tujuan utama pembuatan biogas adalah untuk mengisi kekurangan atau mensubtitusi sumber energi. di daerah pedesaan maupun kota sebagai bahan bakar keperluan rumah tangga terutama memasak dan lampu penerangan, disamping itu dari proses produksi biogas akan dihasilkan sisa kotoran (sludge) yang dapat langsung dipergunakan sebagai pupuk organik pada tanaman atau budidaya pertanian limbah biogas yaitu kotoran (sludge) yang telah hilang gasnya merupakan pupuk organik yang sangat kaya akan unsur-unsur yang dibutuhkan oleh tanaman bahkan unsurunsur tertentu seperti protein, selulose, lignin tidak dapat digantikan oleh pupuk kimia. 
Biogas mulai diperkembangkan di Indonesia sepenulisr tahun 1970 namun, tingginya penggunaan bahan bakar minyak tanah dan tersedianya kayu bakar menyebabkan penggunaan biogas menjadi kurang berkembang. Teknologi biogas mulai berkembang kembali sejak tahun 2006 ketika kelangkaan energi menjadi topik utama di Indonesia (Renilaili dan Pasmawati, 2016). Energi yang dihasilkan adalah: (1) Energy yang bersih dan dapat diperbaharui, (2) Bahan bakar biogas yang dihasilkan berkualitas tinggi, (3) Dari lingkungan, keuntungan yang diperoleh adalah mengurangi pencemaran lingkungan (polusi).

Penelitian ini bertujuan untuk mengetahui seberapa besar persentase biogas yang dihasilkan dari bahan baku enceng gondok dan seberapa besar persentase hasil biogas yang terjadi apabila enceng gondok dicampur dengan kotoran sapi. Penelitian ini juga berfungsi untuk mengetahui persentase dari biogas yang dihasilkan dari bahan baku yang dipakai, juga dengan adanya penelitian ini penulis bisa membuat biogas yang sesuai dengan kebutuhan dan komposisi . yang tepat untuk mendapatkan biogas yang optimal. Bagi masyarakat awam yang ingin meproduksi biogas yang baik dapat menggunakan cara-cara ini, agar dalam pembuatan diperoleh biogas yang optimum sesuai dengan keinginan.

\section{METODOLOGI PENELITIAN}

Pada tahap pada pengujian pendahuluan ini akan dilaksanakan pengujian pembuatan digester biogas dengan sekala kecil, yaitu dengan memanfaatkan galon air sebagai media digester proses anarob fermentasi . Bahan baku utama enceng gondok bercampur dengan kotoran sapi berdasarkan dari pengujian biogas digester dengan sekala kecil, bertujuan untuk menekan angka kegagalan dalam proses pengujian biogas sekala drum.

Adapun hasil pengujian biogas ini diharapkan dapat mengetahui sebagai berikut: (1) Berapa perbandingan bahan baku komposisi biogas yang sesuwai untuk menghasilkan kandungan gas metana $\left(\mathrm{CH}_{4}\right)$ yang optimal, (2) Mengetahui sekala waktu dari proses fermentasi biogas, (3) Mengetahui hasil dari tekanan kandungan gas metana $\left(\mathrm{CH}_{4}\right)$ dari proses anarob biogas, (4) Mengetahui volume dari komposisi bahan baku dari biogas. Bahan - bahan perencanaan rancangan digester biogas sekala kecil adalah galon air mineral, katup pengatur gas berupa 
keran, selang pelastik 1 inci, termometer, manometer, dan ban sebagai penampung gas.

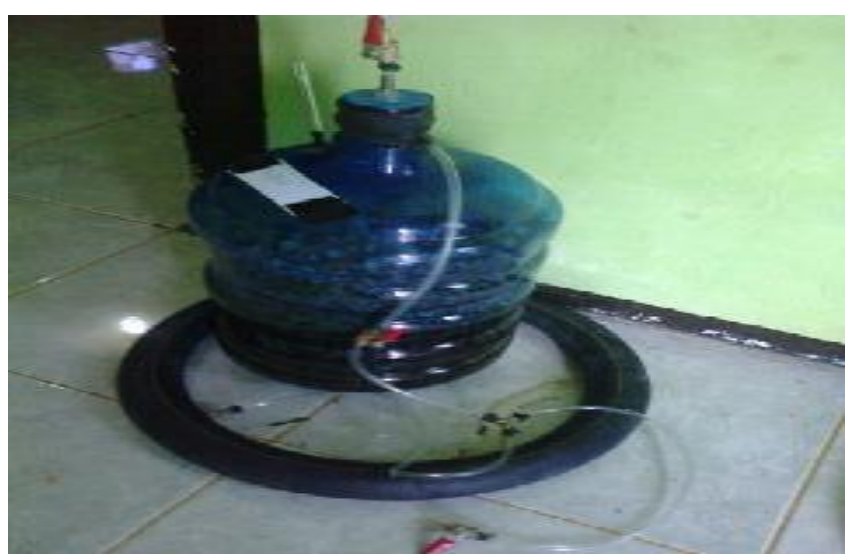

Gambar 2. Skema biogas galon

\section{Bahan baku yang digunakan}

Fases sapi yang digunakan dalam dalam kondisi segar karena lebih mudah di proses dibandingkan dalam kondisi kering. Eceng gondok dicacah dengan ukuran 2-3 cm pada bagian batang dan saja. Setelah itu, bahan ditimbang sesuai dengan kebutuhan. Pelaksanaan pengujian biogas ini dilakukan dengan 2 tahapan pengujian percampuran bahan isian diantaranya: (1) Enceng gondok 25 $\%$ : Kotoran sapi 75\% : Air 5 liter; (2) Enceng gondok $75 \%$ : Kotoran sapi 25\%: Air 5 liter; dan (3) Enceng gondok 50 \% : Kotoran sapi 50\% : Air 5 liter

\section{Penanganan biogas}

Dalam pembuatan biogas untuk mendapatkan produksi gas yang maksimal ada beberapa penanganan biogas selama proses pemeraman yang perlu diperhatikan diantaranya: (1) Peletakan digester sesuaikan dengan temperature lingkungan sepenulis ruangan suhu kamar; (2) Hindari dari paparan sinar matahari langsung selain berpengaruh pada temperatur juga mengakibatkan tumbuhnya lumut pada dinding digester; (3) Hindari dari kebocoran pada pralatan biogas karena akan mengakibatkan suatu kegagalan terbentuknya gas pada saat pengujian.

\section{PEMBAHASAN}

Hasil pengujian biogas didata setiap jam 10 pagi dengan mendata suhu, tekanan, berat biogas. Hasil pengujian biogas skala galon 20 liter dengan 3 perbandingan komposisi ditunjukkan pada Tabel 1. Pencapaian tekanan gas tertinggi dari ketiga desain eksperimen terjadi pada desain eksperimen 
25\%:75\%:5 liter terjadi pada hari ke 6, yaitu sebesar $900 \mathrm{~Pa}$, sedangkan tekanan gas tertinggi pada eksperimen 75:25:5 yaitu pada hari ke 6, Sebesar $600 \mathrm{~Pa}$, dan tekanan gas eksperimen 50:50:5 yaitu pada hari ke 6, Sebesar $700 \mathrm{~Pa}$.

Tabel 1. Hasil pengujian biogas pada Galon

\begin{tabular}{ccccccc}
\hline $\begin{array}{c}\text { Massa } \\
\text { Isian }\end{array}$ & Hari ke- & $\begin{array}{c}\text { Waktu } \\
\text { Pengujian }\end{array}$ & $\begin{array}{c}\text { Suhu } \\
\left({ }^{\circ} \mathrm{C}\right)\end{array}$ & $\begin{array}{c}\text { Tekanan } \\
(\mathrm{Pa})\end{array}$ & $\begin{array}{c}\text { Berat Gas } \\
(\text { gram })\end{array}$ & $\begin{array}{c}\text { Volume } \\
(\text { Liter })\end{array}$ \\
\hline Enceng & 1 & 10,00 & 37 & - & 425 & 15 \\
Gondok & 3 & 10,00 & 38 & 300 & 440 & 15 \\
2,5 kg; & 6 & 10,00 & 39 & 900 & 520 & 15 \\
kotoran & 9 & 10,00 & 39 & 700 & 560 & 15 \\
sapi 7,5 & 12 & 10,00 & 38 & 300 & 575 & 15 \\
kg; air 5 L & 15 & 10,00 & 37 & 200 & 580 & 15 \\
\hline Enceng & 1 & 10,00 & 37 & - & 425 & 15 \\
Gondok & 3 & 10,00 & 37 & 200 & 430 & 15 \\
7,5 kg; & 6 & 10,00 & 38 & 600 & 455 & 15 \\
kotoran & 9 & 10,00 & 38 & 400 & 475 & 15 \\
sapi 2,5 & 12 & 10,00 & 37 & 200 & 480 & 15 \\
kg; air 5 L & 15 & 10,00 & 37 & 200 & 485 & 15 \\
\hline Enceng & 1 & 10,00 & 37 & - & 400 & 15 \\
Gondok & 3 & 10,00 & 37 & 200 & 405 & 15 \\
5,0 kg; & 6 & 10,00 & 39 & 700 & 455 & 15 \\
kotoran & 9 & 10,00 & 39 & 600 & 460 & 15 \\
sapi 5,0 & 12 & 10,00 & 38 & 300 & 470 & 15 \\
kg; air 5 L & 15 & 10,00 & 38 & 200 & 475 & 15 \\
\hline
\end{tabular}

\section{Pengujian dengan Menggunakan Digister Drum Plastik}

\section{Volume tabung pencerna}

Kapasitas adonan hanya $150 \mathrm{~kg}$ dan digester yang digunakan merencanakan menggunakan drum plastik 200 liter (Gambar 3). Adapun spesifikasi drum adalah sebagai berikut diameter tabung luat (Dl) $52,2 \mathrm{~cm}$, diameter dalam (Dd) $52 \mathrm{~cm}$, tinggi tabung $=92 \mathrm{~cm}$, dari speaifikasi drum tersebut maka dapat di ketahui volume drum dengan rumus berikut:

$$
\mathbf{V}=\pi \boldsymbol{r}^{2} \times \mathbf{t}
$$

Dimana :

$$
\begin{aligned}
& \mathrm{V}=\text { volume biogas }\left(\mathrm{m}^{3}\right) \\
& \mathrm{r}=\text { jari-jari drum penampung }(\mathrm{m}) \\
& \mathrm{t}=\text { selisih tinggi drum }(\mathrm{m})
\end{aligned}
$$

Adapun Perhitungan volume digester

$$
\begin{aligned}
\mathbf{V} & =\pi \boldsymbol{r}^{2} \mathbf{x} \mathbf{t} \\
& =3,14 \times(26)^{2} \times 92 \\
& =195,282,88 \mathrm{~cm}^{3} \\
& =0,195 \mathrm{~m}^{3}
\end{aligned}
$$


$=195,28$ liter $=200 \mathrm{~L}$

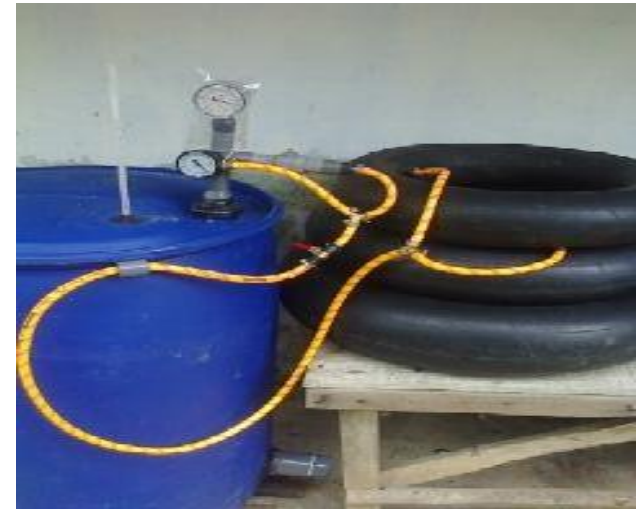

(a)

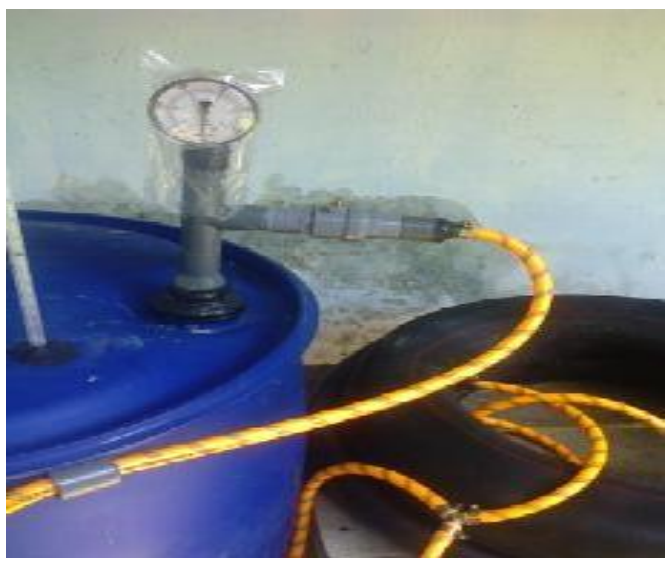

(c)

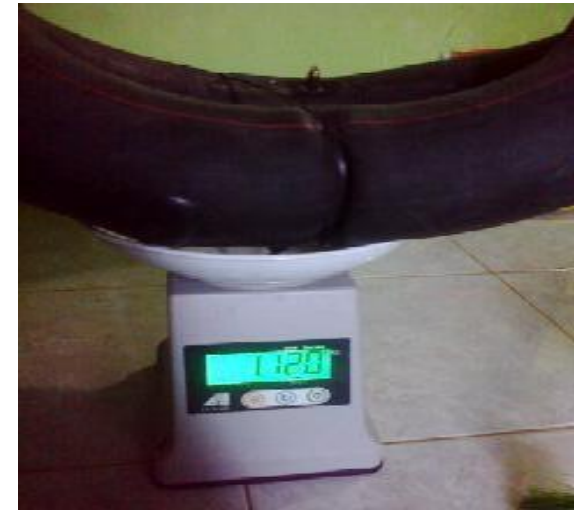

(b)

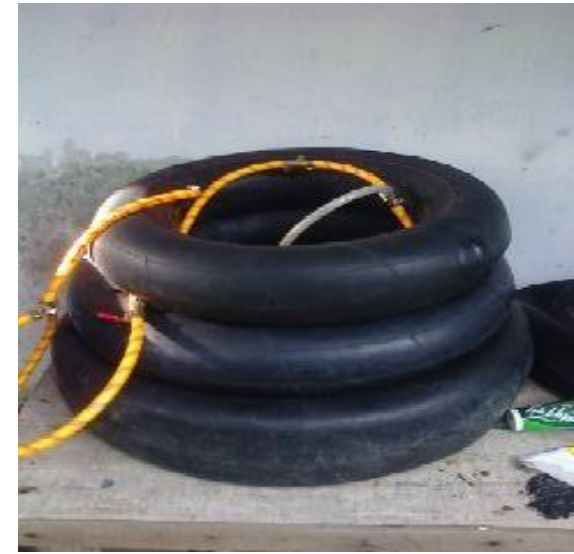

(d)

Gambar 3. Skema digester drum plastik. (a) Kontrol Manometer; (b) Penimbangan Berat Gas; (c) Posisi Manometer Penuh; (d) Penampungan Gas pada Ban.

\section{Proses Pengujian}

\section{Banyaknya isian digester}

Dalam perhitungan menentukan jumlah kotoran sapi dan enceng gondok yang dibutuhkan untuk menghasilkan biogas. terlebih dahulu dihitung masa jenis kotoran sapi dan enceng gondok dengan mengunakan rumus masa jenis (Saputri dan Trihadiningrum, 2010).

\section{Kotoran sapi}

Diketahui masa kotoran sapi di timbang seberat $15 \mathrm{~kg}$ dengan mengunakan ember dengan volume ember $0,020 \mathrm{~m}^{3}$ sehingga masa jenis kotoran sapi adalah :

$\rho=\frac{15}{0,020}=750 \mathrm{~kg} / \mathrm{m}^{3}$ 
Enceng gondok, masa enceng gondok di timbang seberat $12 \mathrm{~kg}$ dengan menggunakan ember dengan volume ember $0,020 \mathrm{~m}^{3}$, sehingga masa jenis enceng gondok adalah : $=\frac{12}{0,020}=600 \mathrm{~kg} / \mathrm{m}^{3}$.

Masa jenis air adalah $1000 \mathrm{~kg} / \mathrm{m}^{3}$

1. Volume digester $=0,195 \mathrm{~m}^{3}$ atau 200 liter

2. Volume (v) bubur kotoran sapi dan enceng gondok adalah $3 / 4$ dari volume digester dengan perbandingan $25 \mathrm{~kg}: 75 \mathrm{~kg}$ dan penambahan air 50 liter.

$$
V=\frac{3}{4} \times 0,195 \mathrm{~m}^{3}=0,1425 \mathrm{~m}^{3}
$$

Jadi 0,1425 adalah volume digester yang di isi bubur kotoran sapi bercampur cacahan enceng gondok. Jadi diperlukan $0,025 \mathrm{~m}^{3}$ enceng gondok dan dibu tuhkan $0,075 \mathrm{~m}^{3}$ kotoran sapi dan air sebagai pengencer $0,050 \mathrm{~m}^{3}$.

3. Masa kotoran sapi (Ms) yang dibutuhkan adalah Volume kotoran sapi x masa kotoran sapi

$$
\mathrm{Ms}=0,075 \mathrm{~m}^{3} \times 750 \mathrm{~kg} / \mathrm{m}^{3}=56,25 \mathrm{~kg}
$$

4. Masa enceng gondok (Me) yang dibutuhkan adalah Volume enceng gondok $\mathrm{x}$ masa jenis kotoran sapi $\mathrm{Me}=0,025 \mathrm{~kg} / \mathrm{m}^{3} \times 600 \mathrm{~kg} / \mathrm{m}^{3}=15 \mathrm{~kg}$

5. Masa air (Ma) yang dibutuhkan adalah Volume air $\mathrm{x}$ masa jenis air Mair $=0,050 \mathrm{~m}^{3} \times 1000 \mathrm{~kg} / \mathrm{m}^{3}=50 \mathrm{~kg}$

Hasil pengujian biogas dengan cara yang sama pada Drum 200 liter dengan perbandingan 25\%:75\%:50 liter, ditunjukan pada Tabel 2. Tekanan gas yang dihasilkan selama 21 hari tekanan gas terliha pada hari ke 1 dengan tekanan gas 3.600.Pa, dan meningkat 5.000.Pa pada hari ke 3-5 tekanan gas terbaca dimanaometer P2 hari 6-9 10.000 pa. Sunaryo (2014) menyebutkan bahwa biogas yang dihasilkan kotoran sapi selama proses fermentasi adalah 27,35 L/Kg. Sedangkan dengan penelitian Wardani dan Warsono (2013) yang menyelidiki potensi biogas dari eceng gondok dan peluang untuk mengoptimalkan instalasi biogas mikro hasilnya adalah 11,3 liter biogas dapat dihasilkan dari satu kilogram eceng gondok segar. 
Tabel 2. Hasil pengujian biogas pada Drum dengan perbandingan isian $25 \%$ enceng gondok : $75 \%$ kotoran sapi : $50 \mathrm{~L}$ air

\begin{tabular}{cccccc}
\hline Hari ke- & $\begin{array}{c}\text { Waktu } \\
\text { pengujian }\end{array}$ & $\begin{array}{c}\text { Suhu } \\
\left.\mathbf{(}^{\circ} \mathbf{C}\right)\end{array}$ & $\begin{array}{c}\text { P1 Tekanan } \\
\mathbf{( P a )}\end{array}$ & $\begin{array}{c}\text { P2 } \\
\text { Tekanan }\end{array}$ & $\begin{array}{c}\text { P3 } \\
\text { Tekanan } \\
(\mathbf{P a})\end{array}$ \\
\hline 1 & 10.00 & 37 & 3.600 & - & 1.800 \\
2 & 10.00 & 34 & 4.400 & - & 2.200 \\
3 & 10.00 & 34 & 5.000 & - & 3.800 \\
4 & 10.00 & 38 & 5.000 & - & 2.300 \\
5 & 10.00 & 42 & 5.000 & - & 3.600 \\
6 & 10.00 & 38 & - & 10.000 & 2.300 \\
7 & 10.00 & 38 & - & 10.000 & 3.300 \\
8 & 10.00 & 39 & - & 10.000 & - \\
9 & 10.00 & 38 & - & 10.000 & - \\
10 & 10.00 & 36 & 5.000 & - & 2.300 \\
11 & 10.00 & 40 & 5.000 & - & 3.500 \\
12 & 10.00 & 38 & - & 10.000 & 1.500 \\
13 & 10.00 & 38 & - & 10.000 & 2.600 \\
14 & 10.00 & 40 & 4.300 & - & 3.400 \\
15 & 10.00 & 40 & 4.400 & - & 1.600 \\
16 & 10.00 & 38 & 4.400 & - & 2.500 \\
17 & 10.00 & 39 & 4.700 & - & 3.600 \\
18 & 10.00 & 40 & 4.500 & - & 1.700 \\
19 & 10.00 & 36 & 3.700 & - & 2.500 \\
20 & 10.00 & 38 & 4.500 & - & 3.200 \\
21 & 10.00 & 37 & 4.400 & - & 4.000 \\
\hline
\end{tabular}

\section{KESIMPULAN}

Berdasarkan hasil dari pengujian pembuatan dan pengujian biogas yang telah dilaksanakan dengan ini dapat diambil kesimpulan sebagai berikut.

1. Berdasarkan hasil dari pengujian biogas skala Galon perbandingan $25 \%$ : 75\% : Air 5 liter adalah hasil yang paling optimal selain mendapat hasil yang optimal perbandingan tersebut bisa mengeluarkan gas selama 15 hari dengan tekanan maksimal hari ke 6, yaitu sebesar $900 \mathrm{~Pa}$ dan $200 \mathrm{~Pa}$ pada hari ke 15.

2. Berdasarkan hasil pengujian biogas pada drum 200.Ltr dengan perbandingan 25\% : 75\% : Air 5 lite yang telah dilakukan gas bisa keluar selama 21 hari waktu fermentasi. pencapaiyan tekanan gas yang paling optimal adalah pada hari ke 7 mampu menghasilkan tekanan gas sebesar 10.000 Pa dan 4400 Pa pada hari ke 21

\section{DAFTAR PUSTAKA}


Nadiriah, N. dan Triwikantoro. 2014. Pemurnian produksi biogas dengan metode absorbsi menggunakan $\mathrm{Ca}(\mathrm{OH} 2)$. Jurnal Sains dan Senipom ITS, 3(2): 2337-3520.

Darnegsih. 2016. Pengaruh perbandingan bahan baku terhadap biogas dari enceng gondok dengan mengunakan kotoran sapi. Jurnal of Chemical Proses Enginering, 1(1): 9-13.

Renilaili, R. dan Pasmawati, Y. 2016. Biogas enceng dan feses sapi sebagai energi alternatif. Proceeding Simpossium Nasional RAPI XV, pp. 486-492.

Saputri, A.R. dan Trihadiningrum, Y. 2010. Pemanfaatan biogas enceng gondok dari kolam pengolahan grey Water sebagai penghasil biogas. Surabaya: Fakultas Teknik Sipil ITS.

Sunaryo, S. 2014. Rancang bangun reactor biogas untuk pemanfaatan limbah ternak sapi didesa Limbang Kabupaten Banjar Negara. Jurnal PPKM UNSIQ, 1(1): $1-10$.

Wardani,E.K. Warsono, B.D, 2013. Perencanaan biodigester tinja manusia dan kotoran ternak sekala komunal rumah tangga di Kecamatan Ngancar, Kabupaten Kediri. Jurusan Teknik Lingkungan, Fakultas Teknik Sipil dan Perencanaan ITS. 